University of Colombo Review (Series III),

Vol. 2, No. 1, 2021

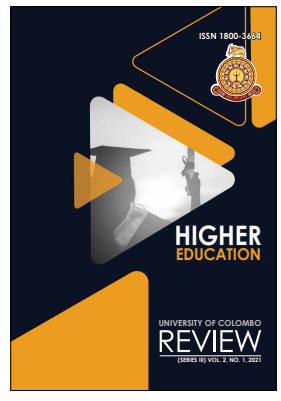

\title{
"Marrying the Monster": World Bank Loans and English Language Projects in Sri Lankan Universities
}

\author{
Kaushalya Perera \\ Senior Lecturer, Department of English, University of Colombo
}

ABSTRACT
A large portion of the World Bank's loans for universities in Sri Lanka
is provided for English language learning programs. The justification
has been the necessity of English language proficiency for creating
an employable graduate, and in so doing, to advance the economic
prospects of the country. This is in line with the World Bank's global
education policy agenda. Even though the Bank has provided Sri Lanka
loans for the development of higher education for two decades, there
is little independent research on their impact. There is also a gap in
our knowledge of its policy on language education. This article aims to
contribute to these areas, drawing on a qualitative study of the English
language component in World Bank funded projects in Sri Lankan
universities from 2003-2016. It uses data from semi-structured
interviews with academics who were involved in the projects and
selected documents from the bank's projects. Three principal themes
are discussed: a) the coercive conditionalities that accompany these
loan projects, b) participants' queries on whether the real needs of the
student population were met, and c) changes to academic practices.
The article ends with recommendations and a call for further research.
ELT, ESL, higher education, language policy and planning, Sri Lanka,
universities, World Bank

Suggested Citation: Perera, K. (2021). "Marrying the monster": World Bank loans and English language projects in Sri Lankan universities. University of Colombo Review (New Series III), 2 (1), 42 - 60.

(c) 2021 The Authors. This work is licenced under a Creative Commons Attribution 4.0 International Licence which permits unrestricted use, distribution, and reproduction in any medium, provided the original work is properly cited. 


\section{Introduction}

"I don't know why all these huge amounts of money y'know?" asked an academic I interviewed in mid-2014, referring to the funds allocated by the World Bank for English language proficiency programs in Sri Lankan universities. Since 2003 when the first loan cycle began, English language proficiency has been a major component of the World Bank's three loan cycles for higher education in the country. The rationale has been the country's need for employable graduates.

Sri Lanka has been a recipient of the World Bank's loans since 1954 (e.g., the Aberdeen Laxapana project), but loans for higher education, or more specifically the university sector, only began in 2003. This is several years after the World Bank began investments in education in other regions, which have been the focus of greater scholarly, critical attention (Banya \& Elu, 2001). Its policies on language education have received less sustained attention, however, from scholars of education and applied linguistics (e.g., Mazrui, 2000). Nor are there many studies focusing on the experiences of loan recipients, with the exception of Collins and Rhoads (2010). Despite a large body of work critiquing the World Bank's lending for higher education in other parts of the world, its lending to Sri Lankan universities is curiously under-researched.

This article aims to address these gaps by focusing specifically on the conditions of World Bank-funded English as a Second Language (ESL) projects in Sri Lankan universities during the first two loan cycles: Improving Relevance and Quality of Undergraduate Education or IRQUE (2003-2010) and Higher Education for the Twenty-First Century or HETC (2010-2016). Through interviews with academics engaged in ESL programs during this period, the article presents three main themes that were discussed: coercive conditionalities, real English language teaching (ELT) needs, and academic practices.

I first review current literature on the World Bank's education policies and its language education policies. A brief overview of the World Bank's loan cycles for the university sector in Sri Lanka, paying special attention to its ESL focus follows. The article ends with the three main themes that emerged from the interviews about the first two loan cycles, and a discussion on the implications of the findings.

\section{The World Bank's Education and Language Policies}

The Bank's involvement in education has been well studied since the 1980s, when they became a dominant force in this sector (Torres \& Schugurensky, 2002). Yet, as Stephen P. Heyneman (2003), a former Bank staffer states, it "is also the object of considerable criticism" (p. 315). Indeed, it has proven exceptionally difficult to locate positive accounts of the Bank by independent scholars other than the Bank's own publications or those produced by institutions funded by the Bank. The Bank's role in bringing about systemic changes to education (including higher education) has been recorded across regions of Africa, Latin America, and Europe, and are overwhelmingly critical (Brock-Utne, 2007; Rutkowski, 2007; Torres \& Schugurensky, 2002; Verger et al., 2014). Even in the rare instances where a strategy such as imposing user fees (or tuition fees by students) in higher education is supported by authors, authors are still critical of the overall policy orientation 
(e.g., Banya \& Elu, 2001). The Bank's involvement in Asian higher education institutions has been studied more sporadically, perhaps because its loans for education in the Asian region has been more recent (Burford \& Mulya, 2019; Collins \& Rhoads, 2010; Regmi, 2016). However, studies critical of its involvement in national education policies have emerged from Nepal and Bangladesh (Regmi, 2019; Rumnaz Imam, 2005).

A criticism from both within and outside the Bank has been its long-term adherence to policies modeled on a theory of human capital, which sees "education as an investment through which individuals, corporations and nations can maximize their economic growth and prosperity" (Regmi, 2015, p. 134-135). Heyneman (2003), in his review of the Bank's education policy history, discloses that the Bank faced "unprecedented internal protest" (p. 328) in the mid-1990s against the "short education policy menu", which included recommendations to "increase the private cost for attending universities" and "to install loan schemes to set off the financial burden" on the population that needs higher education (p. 325). Despite the criticism, these still remain priorities in the Bank's higher education agenda. The Bank has also been critiqued for a narrow economic orientation towards education, and its disregard of other factors such as human rights violations in borrower countries and diverse cultural understanding of education (Jones, 2007).

Another major cause for concern has been the Bank's conditionalities linked to the privatizing of higher education. Ample evidence exists of its forceful behavior regarding changes to higher education systems in recipient countries (Heyneman, 2012; Regmi, 2016; Wikramanayake, 2015). Regmi (2016) identifies privatization as one of the "three key tenets of neoliberalism" that guides the Bank's education policies, the other two being marketization and decentralization (p. 43). Requirements that borrowing countries change economic regulations according to Bank dictates (see Burford \& Mulya, 2019) are now achieved through "prior actions", i.e., changes to national policies and governance systems which have to be in place in order to receive loans (Regmi, 2016; Rutkowski, 2007). In both Nepal and Bangladesh, reforms urged by the Bank were enabled by changes to national laws on higher education (Kabir, 2020; Regmi, 2019). In Sri Lanka, Damaris Wikramanayake (2015) reveals that high level meetings with donor representatives were led by Bank officials rather than by government officials. Given the massive amount of loans taken from the Bank, Sri Lankan government officials "could not afford to be critical" of the Bank (p. 216). In the higher education sector, World Bank loans have meant the imposition of various mechanisms that are framed as enhancing the quality and performance of universities. This illustrates the Bank's command over policy-making institutions in South Asia and its high level of influence on national higher education policies.

A major problem discussed across a large and widespread body of the literature is the Bank's promotion of changes that have resulted in a deterioration of public higher education services (Burford \& Mulya, 2019; Collins \& Rhoads, 2010; Heyneman, 2003; Torres \& Schugurensky, 2002). The Bank advises substantive reductions in state expenditure on higher education, a phenomenon that has impacted universities across Africa (Banya \& Elu, 2001), Latin America (Torres \& Schugurensky, 2002), and now, South and South East Asia (Burford \& Mulya, 2019; Kabir, 2020; Regmi, 2019). This reflects its ideology of 
education as a market good rather than a social good. Torres and Schugurensky (2002) note, of Latin American universities, that a "combination of privatization and government control constitutes the trademark of university restructuring" in the era after Bank funding (p. 445). This is also true of universities in Asian countries such as Indonesia, Thailand, Nepal, and Bangladesh since the 1990s, when they started receiving Bank loans (Burford \& Mulya, 2019; Kabir, 2020; Regmi, 2019). Such steps have been detrimental to countries with weaker economies and larger communities of low-income groups unable to afford privatized higher education. The dependency that continuous loan-giving creates in recipient countries has also been cited as a serious problem (Collins \& Rhoads, 2010).

Even though Sri Lanka started borrowing from the World Bank for higher education approximately twenty years ago, a majority of publications on this are by the Bank itself (e.g., Dundar et al., 2017) or are merely reports on the performance of specific projects (e.g., Senaratne \& Gunarathne, 2010). Only a handful of work exists as independent research on the Bank's involvement in Sri Lankan education in general (Perera \& Canagarajah, 2010; Punchi, 2001; Wickramasinghe, 2018; Wikramanayake, 2015). Of interest is Punchi's (2001) article on general education, which discusses the World Bank as an agent of globalization and describes the conditionalities attached to its lending. Punchi reminds us that Sri Lanka's high human development levels are a result of high state investment in education in the early post-colonial era, successful due to the adoption of local languages as mediums of educational instruction. He advocates a national education policy that continues its commitment to free education in local languages for the benefit of disadvantaged groups. Wikramanayake (2015), evaluating the effectiveness of donor aid, including that of the World Bank, to Sri Lanka's education sector, finds that the sector has been directly affected by conditionalities related to economic policies, and that the focus has been on areas that are a priority for donors. Wikramanayake also reveals tensions in donor agencies over the dominant role played by the World Bank in Sri Lanka's education sector.

Scholars agree that the Bank prioritizes English as a means of access to the global marketplace and that this is to the detriment of local languages (Phillipson, 2001; Rumnaz Imam, 2005). For instance, while the Bank promoted mother tongue or indigenous language education in primary schools in the African region, it was primarily as a means to better transition later to secondary education in colonial (second) languages, including English (Brock-Utne, 2010; Mazrui, 2000). In Alamin Mazrui's (2000) succinct terms, the Bank "suffers from an Anglo-linguistic bias in its attempts to determine the destiny of the world" (p. 45). In South Asia, where English is a dominant presence due to historical reasons, the Bank's insistence that English language proficiency is indispensable to a "quality" university education has led to a neo-colonial resurgence of ideologies related to English. However, this has been rarely addressed. An exception is Syeda Rumnaz Imam's (2005) analysis of Bangladeshi language education policies, which frames English rather than Bangla as a purveyor of "secure high profile jobs" and access to life abroad (p. 480). Rumnaz Imam draws connections between these language ideologies, the Bangladeshi government's interest in more private education, and the Bank's financial investments in the country. For Sri Lanka, Perera and Canagarajah (2010) highlight a case where a faculty converted to 
English medium instruction, despite the understanding that it would harm students with low English proficiency, using Bank funds and following its ideology of English as the language of employability.

\section{World Bank Funded ELT Projects in Sri Lankan Universities}

Since 2003, the Bank has provided US\$180.3 million in the form of three consecutive lending cycles to Sri Lankan universities (see details in Table 1). In all three loan cycles, ESL is a core component. Therefore, Departments of English Language Teaching (DELTs) were always part of these projects. ${ }^{1}$ At the same time, other departments and faculties also submitted proposals to enhance ESL proficiency of their students and staff (e.g., the "Improve student centred teaching-learning and skills development" activity under the IRQUE project of the Department of Accountancy (Senaratne \& Gunarathne, 2010). While in some instances such projects were formulated with the support of DELT staff, in others they were completely independent projects.

Table 1: Details of World Bank Loans for the Higher Education Sector 2003-2023

\begin{tabular}{|l|c|c|}
\hline Name of loan cycle & Duration & $\begin{array}{c}\text { Loan amount } \\
\text { (in US\$) }\end{array}$ \\
\hline $\begin{array}{l}\text { Improving Relevance and Quality in } \\
\text { Undergraduate Education (IRQUE) }\end{array}$ & $2003-2010$ & 40.3 million \\
\hline $\begin{array}{l}\text { Higher Education for the Twenty-First Century } \\
\text { Project (HETC) }\end{array}$ & $2010-2016$ & 40 million \\
\hline $\begin{array}{l}\text { Accelerating Higher Education Expansion and } \\
\text { Development Operation Project (AHEAD) }\end{array}$ & $2017-2023$ & 100 million \\
\hline
\end{tabular}

Bank loans to the universities are disbursed to individual universities through the Ministry of Higher Education (currently part of the Ministry of Education) and the University Grants Commission (UGC). According to the IRQUE Development Credit Agreement (Legal Dept of World Bank, 2003), both state and private institutions could apply for funds through these loans. The loans are not repaid by universities individually but are repaid by the Sri Lankan government as part of the national debt.

The long-term austerity that universities faced was possibly a reason for the avidity with which Bank loans were greeted by Sri Lankan universities. Reductions in state funding had reduced the quality of education by the early 2000s (Samaranayake, 2016). While state expenditure on education overall in 2003 (when the first loan cycle started) was already a mere $2.5 \%$ of the GDP, it reduced to $1.86 \%$ of GDP as the second loan cycle began in 2010 (Wikramanayake, 2015). Despite this, and a consequent lack of infrastructural and material resources, universities were also required to admit increasingly higher numbers of undergraduates.

The need for English language proficiency and Information Technology (IT) skills has been a consistent thread in the Bank's discourse. The World Bank Country Diagnostic (World Bank Group, 2015) stated that "over 75 percent of employers expect a high-skilled 
worker to know English and have computer skills, but only 20 percent of Sri Lankans are fluent in English and only 15 percent can use computers" (p. 5). The Bank sees proficiency in English and IT as leading to "enhance[d] technological skills and learning potential", which would in turn enhance prospects in the job market (Project Appraisal Document IRQUE, 2003, p. 48) and transform Sri Lanka's labor force to a global standard.

The Bank's ideologies on English and employability are simplistic. Ranasinghe \& Logendra (2015) have pointed out that the large body of literature on employability and employable attributes does not rest on English language and IT. Other factors also impact the employment of individuals, which are not taken into account in Bank policies regarding Sri Lanka. There are no discussions, for instance, on class-based inequalities that affect employment opportunities. Furthermore, knowledge of English is a core component of both the IRQUE and HETC loan projects, with little evidence in the documentation that this was decided in consultation with universities. English language scores used as original target values to measure improvements due to IRQUE project implementation were "retrofitt[ed]" according to the Bank's Implementation Completion and Results Report (2010) - presumably assigned as such after implementation. The initial Project Appraisal Document also "did not include either baseline data, or end-of-project targets" (2003, p. 6).

There have also been some inconsistencies in the Bank's own reports of project successes and rationales for the need of consequent loan cycles. The first Project Appraisal Document (2003) of the Bank argued that the IRQUE project "has the potential to decrease unemployment and under-employment among graduates through training in IT and English, and other skills in demand in the labor market" (p. 19). In the second loan cycle as well, funds were set aside to reform existing ESL programs in the universities since "English language skills certification programs are not linked to the labor market" (Aturupane, 2011 , p. 2). Despite the Bank's reports that " $84 \%$ of the students are participating in and benefitting from the English language skills certification programs" through the HETC (Aturupane, 2016, p. 4), Bank consultants rationalized in a 2016 workshop with DELT academics, that a third loan cycle was needed since the English language component was not successful (field notes, May 2016).

\section{The Interviews}

As shown in the discussion above, available research on World Bank loans to higher education are mostly policy reviews. In response to the need for a different methodology and perspective, this article uses in-depth, semi-structured qualitative interviews as its main mode of data collection. Semi-structured interviews are frequently used in qualitative research in applied linguistics as a means of capturing the experiences and giving voice to individuals in the research setting (Talmy, 2010). Data for this article is drawn from six academics affiliated to five departments at three universities. The departments included were not limited to DELTs. However, all participants have worked on Bank-funded English language projects. The interviews were conducted during 2011-2017 and the topic was the first two loan cycles of the Bank - IRQUE and HETC. The third loan cycle, AHEAD, was not discussed in the interviews. Relevant project documents of the two loan cycles 
discussed, available on the World Bank website, were also consulted. Three main themes emerged from the interviews: coercive conditions, the real needs of students, and changes in academic practices. The next section discusses these themes in detail.

\section{Coercive Conditions}

The projects initiated as part of the Bank's loan cycles are associated with coercion from the Bank itself to participate in the loan cycle, and bureaucratic conditions governing universities. Given that state universities were cash-strapped when the IRQUE loan cycle appeared in 2003, academics were keen to receive these loans, which many perceived to be grants. A senior lecturer said:

It would have been hard [without the loans]. IRQUE and [emphasis in original] the present funding project [HETC] have given us some material resources that we very, very badly needed. We were stuck in the seventies as far as technology was concerned. So that is I think, a plus. Then, I am not sure of the extent but certainly other [things like] just brushing up and renovation and things like that - beautifying the place - has taken place and there has been some funding and that has been a good thing. (Participant X)

Sri Lankan universities in general lack not only technological resources but funds for general upkeep. In this context, World Bank funds enabled universities to refurbish, renovate and extend existing buildings. As procurement plans available on the Bank website show, universities made major investments in infrastructure and technology: computers and multimedia projectors for office work, laptops for staff use and other office equipment such as chairs and air conditioners. These may seem simple needs, but with the low provision of state funding for higher education at the time, state universities existed with the bare minimum in terms of material resources. The IRQUE project especially offered an opportunity for universities to update and procure equipment that were necessities.

However, participants also experienced severe problems during the lifetime of the projects. The priority areas for lending were already established in the credit agreements and project appraisal documents. These were identified at meetings prior to the official start of the lending process and were formulated according to the government's policy priorities, the Bank's priorities and its experience in other sectors and countries (Project Appraisal Document IRQUE, 2003; Project Appraisal Document HETC, 2010). Theoretically, the government's interests should have been aligned with universities' expectations for themselves, e.g., improving resources for undergraduate education by increasing state financial allocations. That the interests of the two parties align cannot be taken for granted, however, given the low allocation of treasury monies for state universities over the years. Having English language proficiency as a core component of IRQUE, and thereafter HETC, meant that to secure funds from that component, universities had to submit proposals via the DELTs or through other departments that offered or proposed English language programs.

At the time of the IRQUE project, some participants were also unaware of Bank processes, such as requirements to submit regular progress reports, procurement plans, etc. and did not realize that the money provided had conditions attached to it. Participant U's experience was: 
Each time you go for a meeting they [the Bank] want you to alter your proposal. Ultimately what you're doing is not what you wanted. In the end it's gone through so [emphasis in original] many enforced revisions. That [was] quite an annoying, painful process."

Invisible regulations and changing conditions were a frequent concern. At times, application procedure and criteria changed during the proposal application period itself. These changes were partly a result of academics' ignorance of project work, as well as the Bank's changing decisions. In relation to IRQUE, these shifts could also have been the result of the project not having a monitoring and evaluation process in place until 3 years into the project (Implementation Completion Report Review, 2011). Some conditions were not made clear at the time of the proposal submission but were notified later. Another participant referred to the stress of gaining approval for a budget for an activity funded by the Bank, and then being told of conditions constraining that spending, while at the same time being held accountable for the approved budget. For example, the Bank approved a language course, and as the project progressed, the team was told that funds were available only for course material development and physical resources (such as computers) but not for payments to teachers. The Bank's representatives would state that "this is what the money's for" and recipients would have to adhere to it, even though the proposed project would become less viable with such constraints (Participant R).

Participants also cite a second set of conditions, that of university bureaucracy. Like other state institutions, universities are governed by state financial regulations and face government audit queries. The steps put in place to prevent corruption, such as obtaining three quotations for each piece of merchandise and obtaining approval from multiple committees for different types of expenditures, made project implementation more difficult. Project coordinators and heads of departments spoke of the frustration brought about by the combination of university procedures and Bank conditionalities. A participant shared her experience of ordering chairs, a specific type of which was necessary to convert a physical space for a particular purpose. Quotations were called for, as per university procedures, but the university committees' approval process took some months. By this time, the first quote was unusable as the chairs had increased in price, the second company lacked the required number of chairs of that specific type, and the third company could not supply that specific type of chair. As a result, while the space was redesigned, it was not equipped in the manner suitable for the purpose. In more than one institution, computers were bought but their installation was delayed due to a lack of cooperation or coordination between different units within universities. Wiring would be delayed or software would not be purchased in time. While the policy discourses of the Bank and the Sri Lankan government worked in tandem, the procedures and work practices at universities were yet to synchronize. These setbacks and problems only became apparent as IRQUE, the first loan cycle, progressed.

Despite the material advantages the loans brought in terms of purchasing equipment etc., academic staff was under great pressure. Participants approved of changes such as English Language Teaching (ELT) classes conducting language activities that had not been done before, with laptops available at least for some classes, and language labs at some 
universities. Senaratne and Gunarathne (2010), for example, comment on the popularity of the language lab established at a Department of Accounting. Yet, as Participant U stated, "It involves a lot of work for which nobody's going to get paid so nobody's scrambling to do it." While some staff members were paid additionally for some of the associated responsibilities, others were not. Given the centrality of ESL programs to Bank-funded projects in universities, the time and energy of DELT staff were constantly siphoned into proposal writing, implementation or reporting on the progress of the IRQUE and HETC projects. Since universities expect the support of DELT staff for writing proposals and applications in English, this occurred regardless of whether the project was a DELT (or ELTU) initiative or a faculty or university initiative.

Several participants spoke, therefore, of their reluctance to participate in subsequent rounds of the Bank's loans. Since English-language skills development was a main component, even when academics were reluctant to apply for the money, they felt coerced by their universities or faculties to do so. Participant U referred to "veiled threats and veiled orders" from university authorities. This was due to a few reasons. First, the money given for ESL programs enhanced the material resources of not just one department or faculty but the whole university. Secondly, a large number of staff - both academics and non-academic staff who were indirectly involved with the project - received compensation for activities. As participant X said, "everyone wants that money". The desire for this money, therefore meant that despite their reluctance, many institutions applied for the second and third loan cycles. Participant U's comment that 'it's a kind of enslavement, no. You have to get the grant, you have to write the proposal. Then they don't want to give it to you for exactly what you want to do [emphases in original]", evocatively conveys the cluster of coercive conditions experienced by academics working on these projects.

\section{Real ELT Needs}

As mentioned before, universities (and ELT programs in particular), received essential material resources through the Bank's loan cycles. Yet there were doubts:

Valuable books, multimedia projectors in all those classrooms, fancy chairs... of course we have got money for it but then again these are loan moneys. So we haven't thought of how these moneys will be repaid. So that part is there. (Participant R)

As Participant $\mathrm{R}$ frames it, the issue at hand was whether the benefits exceeded the problems. R was unsure whether academics had seriously considered how Sri Lanka, with its grave economic problems, would repay these loans. At least two participants mentioned that their children would be indebted. Academics also wondered whether the needs that were met were real needs. In some instances, these material resources were neither needed nor suitable. A cogent example is the provision of software for computer-assisted language learning (CALL). The Bank emphasizes computer skills for graduate employability as much as English language. Companies selling CALL software benefitted from these loan cycles, at times approaching universities to market their wares before the project cycle had started. Participant R said of the company they partnered with: "They know only 
technology, they are not ELT experts, so it was a mutual understanding" that ELT staff would design lesson material. However, this did not always happen in the manner prescribed, and different universities had different expectations. One academic in a DELT complained of the problems faced when recruiting a software development company that "knows jackshit about English language teaching doing- developing teaching material" (Participant X). As she described it, they "deliver [lesson material] in a very piecemeal kind of fashion with absolutely no notion of how it fits in". Participant X explained that this was compounded by the fact that the money paid to the companies was "peanuts" and therefore, the work was low priority for the company. Meanwhile, DELT staff were themselves untrained in CALL at the time and were therefore unable to direct these companies appropriately. In at least one institution, subsequent to buying the software, the university decided to reduce spending on purchased software, and the program was unable to renew licenses. These issues of sustainability had not been taken into consideration when planning project activities in the first place.

Such project activities planned without much forethought were frequent points of conversation in the interviews. A relevant example is a little-used language laboratory that was established under IRQUE. As a staff member involved in setting it up claimed, "the primary motive for writing the proposal and asking for this was not even student need. It was because if we ask for this then our chances of getting the grant is higher" (Participant $\mathrm{X}$, emphases in original). However, the language lab or the "computer center" as she called it, was rarely used thereafter. In the interview, she reflected:

We hadn't adequately thought it through. [if it was] not tied to their assessment the students were not going to come... and then if it was ten percent of their course that means... it had to be part of their - the lessons we made for them, and we had to have lecturers who would sit with them, and see it through on the computer and then what they did on the computer could be assessed or not, and somewhere [emphasis in original] in that process the project fell flat.

As this story shows, academics in charge had not been trained in online teaching or blended learning at the time and had, therefore, not foreseen the problems that would occur. Indeed, the Covid-19 pandemic shows us that the majority of academic staff in universities were not prepared for the shift to teaching online, even by 2020. It is not surprising therefore, that DELTs and other academic staff were untrained and unprepared, more than a decade ago. The more serious concern was that the significance of IT and English language for the Bank meant that several universities considered this to be the most suitable means to capture part of the funds.

Such poorly planned activities were evident in projects outside the DELT as well. Participant U, who worked in a non-DELT environment said:

It was planned rather unrealistically. It was not possible to do that [emphasis in original] amount of work within three months...a series of workshops for the staff, a series of workshops for the students, then almost one to one language development help for the staff, more language development activities identified at the workshops for the students, so all that couldn't happen in three months. 
In this and similar cases, activities were "planned rather unrealistically" for two reasons. The first was workload, or the amount of work these projects would add to the regular responsibilities of academics which was not considered. The second, and related, problem was that English language programs designed without the assistance of the DELT meant that in most instances, they were conceptualized by staff with no training or expertise in language teaching or applied linguistics. Badly planned and inefficient project design and management led to a waste of money. A participant described how one consultant was paid twice by two consecutive projects for the same document: once to write it and the second time, to revise it. Food at workshops frequently emerged in the interviews as something that large portions of money were spent on: "chocolate cake for tea-time and a good lunch for lunch time" (Participant X, emphasis in original). Workshops were a staple of Bank funded projects:

People seem to be conducting like y'know bits and pieces of workshops that are not thought through...not enough thought about how they are connected to the lesson and that kind of thing and because there's money for this. And you need to spend the money and you need to have shown some level of activity, no? (Participant X)

Implementing the project entailed taking part in activities that could be recorded for its monitoring and evaluation. Workshops were considered easy activities to implement, that would also allow for allocated moneys to be spent without too much effort. Another example of a waste of money event was recounted by Participant P, who described how one project paid to have lesson material comparable to IELTS made, expecting the British Council to be a reviewer. However, the British Council refused to review it since the material was similar to their own.

The Bank's use of quantitative measures for performance indicators also meant that higher numbers were equated with success. For instance, the Implementation Completion and Results Report (2010) for IRQUE reported that 81 new IT and English programs were started in 12 universities (p. v). Success of this part of the project - increasing English language proficiency to make students employable - was based on this number (indistinguishable from the IT programs), and the claim that the "overall average English Language score increased from 59\% in March 2005 (baseline) to 69\% in December 2008 against the target of $67 \%$ " (p. 9). This claim is questionable, given that scores were "retrofitted", i.e., changed after the fact. The Implementation Completion and Results Report (2016) for HETC also provided a similar quantitative claim of success stating that " $84 \%$ of target students $(76,000)$ completed English language skills certification programs" (p. vii). The story told by the reports coheres with the situation described by participants, where the design and implementation of short-term programs were formulated and implemented piecemeal, instead of engaging in a collaborative dialogue for a more holistic plan to increase English language proficiency across the whole institution. For example, instead of making an overall plan for the whole university, which may have meant one project, multiple departments and faculties implemented a large number of short-term projects that were either a series of short workshops or short-term or one semester courses (e.g., the 81 programs cited above), none of which are suitable for increased proficiency from a 
language teaching perspective. For concrete increases in language proficiency, one course with a larger number of contact hours (approx. 10 hours per week) over a lengthier period of time, such as 1-2 years would have been better suited.

The reliance on solely quantitative measures meant that projects were regarded as successful even when, as shown in this article, there were substantial issues at ground level. Given the well-known reluctance on the part of beneficiaries to jeopardize potential funding avenues, and a lack of monitoring and evaluation systems that takes quality into account, it was unsurprising that issues such as those reported by the participants were not communicated to the Bank. For these multiple reasons, "real needs [of students] get sidelined" (Participant U).

The Bank's simplistic discourse on English is reflected in its use of the word "skill" for English. When a language learning endeavor is conceived of as "skill building", with the connotation that it is something that can be acquired as easily as learning how to send an email or use MS Excel, it also encourages projects to assume that proficiency in English can be easily acquired through some workshops and a few short courses, rather than needing dedicated time, hard work, and practice. This ideological position that English language proficiency is a skill akin to other soft skills is prevalent in state discourses and higher education institutions currently. The uncritical adoption of the Bank's ideology on ESL was termed "marrying the monster" by Participant X: "When you marry the monster you also... are expected to subscribe to the monster's ideology". The coercive conditions attached to loan projects and the superficial understanding of language acquisition make this a highly problematic situation.

Problems also stem from the flawed understanding of the Bank on the role of English in employability and employment (see also Rumnaz Imam, 2005). The Bank considers English language proficiency an employable attribute, i.e., a criterion that has a direct bearing on making a graduate employable. Yet, employability - or having employable attributes - and gaining employment are different and should not be treated as the same (Minocha et al., 2017; Ranasinghe \& Logendra, 2015). Gaining employment relies on multiple factors, foremost amongst them being the availability of jobs in the country, other employable attributes evident in the employee, and socio-cultural factors connected to job opportunities (e.g., access to specific social networks), all of which are ignored by the Bank and universities that follow the Bank's ideology when formulating policy documents related to loan cycles.

From the perspective of English language teaching professionals, universities would have benefited from different strategies and investments. Participant $\mathrm{S}$ felt that the large amount of resources did not make a significant difference:

What I am saying is that in terms of the quality of teaching, like the physical teacher, the teacher teaching better - I'm not sure that that happened because of the World Bank. But if you ask me the conditions of the classroom? Yeah, that improved. (Participant S)

Other participants concurred that a focus on teacher development would have been more useful than the focus on "acquiring material resources" such as "whiteboards, projectors, laptops... printers, what-not paraphernalia" (Participant X). 
Participant Q brought up another factor of importance to ELT professionals - that of time. Most faculties provide 2-4 hours per week for ELT, "which is nothing. That's nothing - to learn a language [emphases in original]", especially for students with low proficiency in English. Participant Q was referring to the correlation between more time with the language and higher proficiency rates (Ortega, 2011), a correlation so well-known in Applied Linguistics circles that it is almost a truism. While universities have demanded that DELTs produce students with higher ESL proficiency and the Bank has made it a priority area, it is rarely that faculties have been allotted more time in the time tables for students' ESL courses. ${ }^{2}$

\section{Changes to Academic Norms and Practices}

The third theme relates to changes in academic norms and practices brought about by Bank-funded projects. One major change is the requirement for academics to acquire the necessary skills to complete the work. While previously most academics had experience in pedagogy and research, Bank-related projects demanded other abilities such as writing project proposals, designing budgets, and monitoring and evaluating project performances. Many academics found this difficult initially, while some thrived on the challenge. Participant T, a junior academic, found this useful: "working with procurement, working with outside people, specifications, preparing TORs, handling workshops. Good experience. Attending meetings with very senior people. I was very new. I have learnt a lot." Senior staff received a different type of experience as well. Participant R, engaged in reviews of HETC grants, valued learning how to conduct "desk reviews and site evaluations". She also appreciated the opportunity to visit other universities, which was not a regular occurrence at that time.

These new experiences appreciated by some participants are also part of the new managerial ethos brought about via Bank-driven educational "reforms". As participant U termed it, "everything is dominated from - prescribed form.... it's about learning [emphases in original] these procedures. It's a matter of conforming to them, almost trying to see it from their [the World Bank's] eyes wage ((like)). It's a new way of looking at [work] no". As Torres \& Schugurensky (2002) noted of this scenario, "academics must develop an entrepreneurial approach" (p. 446). Project work (e.g., monitoring and evaluation, progress reporting), coupled with the new quality assurance mechanisms brought about by the IRQUE and HETC projects, shifted Sri Lankan universities to new managerial work norms. Through these shifts, public universities have become corporatized entities. However, even as academic norms changed to suit lender expectations of accountability and efficiency, these shifts were not reflected upon or critiqued by the participants.

Another important issue that echoed throughout the interviews was the impact of the projects on the capacity for collective action by academics. In 2011 and 2012, the most significant unionized campaigns in the recent history of higher education were organized by the Federation of University Teachers' Associations (FUTA). This coincided with the second loan cycle, the HETC. Participants noted that some academics refused to resign from HETC related positions and in some instances from headship, in 2011, when the union required resignation from voluntary positions. This was due to fears that such resignations would jeopardize the Bank-led projects and related payments. Participants also confessed 
that despite officially being on strike in 2012, they sometimes completed some of the required project work, either voluntarily or by direction.

Such conflicts in loyalties have material consequences. The Bank's loan cycles can impact on the power that academic unions have for collective action given that some of its members may have conflicting interests. If university authorities, the UGC, and the Ministry are able to continue their financial and project-related activities during union campaigns, the collective bargaining power of the unions will be undermined. This is also of significance to the DELTs. The DELTs have historically been marginalized in Sri Lankan universities and DELT academics strive harder for recognition than do academics in other departments. Non-participation in union action may, therefore, affect their standing amongst fellow academics. Even though this was primarily an issue faced by academics in DELTs, they were not the only academics who refrained from strike action during this time. This shows the alarming subversive power of corporatized work norms over collective action, even when that action is on behalf of all academics. The impact of this is an area for further research to better understand the long-term consequences of World Bank loans on university governance and culture.

\section{Conclusion}

This article discussed the World Bank's loan projects at Sri Lankan universities, from the perspective of the academics involved in English language teaching under IRQUE and HETC. Three main themes were highlighted, the first being the conditionalities foundational to the projects, the research participants' experiences of the coercive conditions imposed by their own universities, and bureaucratic regulations. The second area of analysis was on the flawed assumptions of the significance of English in employability, and project targets as against the real needs of the students. The third was on the far-reaching changes to academics' practices and work norms, which include consequences to collective action and bargaining power.

The article revealed the tensions within the World Bank funded projects and their implications for how and whether we continue with these loan projects for our universities. Despite the existence of a robust and critical engagement on the role of English as a tool of class oppression and a barrier to learning historically (Canagarajah, 1999; Gunesekera, 2005; Kandiah, 2010; Parakrama, 1995), universities have uncritically accepted the Bank's notion that English is, and should be, the main criteria for a graduate requiring a job. This is a discourse that applied linguistics and TESOL scholars can, and should, critically engage with, rather than accepting the World Bank's conceptualizing of it.

Where English language programs are concerned, ELT professionals should reconsider their involvement in projects that only pay short-term dividends. More importantly, the Bank's desire to provide loans, and the local institutions' need to take such loans, are opportunities for DELTs and other interested parties in universities to force changes that are useful in the long-term which are also pedagogically sound. Such changes could, for instance, include demanding the allocation of a larger number of hours for English language teaching. It could also include the contestation of ad hoc changes such 
as hasty and poorly-planned conversions to English medium instruction or English-Sinhala bilingual instruction.

There needs to be a change in the Bank's theoretical engagement in relation to education as well, so that education is seen as something other than human capital. A more sophisticated understanding of the role of English in relation to employability and an engagement with the research on employability from around the world would benefit the Bank.

This article also illustrated the problems arising from acquisitive applications for funds and other barriers to the successful implementation of projects. Overly stringent regulations and administrative coercion are problems, irrespective of whether the activity is Bank-funded or not. If institutions decide on the need for external funding, these decisions need to take institutional capacity into account as well as identify the legitimate needs of the institution. We need to know why we want the money, and how we will use it. When embracing large-scale loans, we cannot ignore the impact of that debt on an already encumbered economy. The constricting circumstances caused by miniscule allocations by the Treasury for the management of universities should be addressed at UGC, university administration, and union levels through conversations with the government and relevant Ministries.

All of this calls for more research on the subject (see Wickramasinghe, 2018). As evident in the review of prior literature presented in this article, we are in great need of work that critically assesses the Bank's ideology on language acquisition, its role in Sri Lankan education, local practices related to the Bank, and changes to higher education. As we near the end of the third loan cycle for higher education by the World Bank - and in the event of a possible fourth loan cycle - it is essential that we consider, and become aware of, the implications of these changes.

\section{Acknowledgements}

A preliminary analysis of the related data was presented at the 2017 SLELTA Conference (the international conference of the Sri Lanka English Language Teachers' Association). I would like to thank the members of the audience for their comments. I also deeply appreciate the detailed comments on this version of the article provided by the two anonymous reviewers which helped clarify some of the arguments.

1 During the period when the two projects were active, some of these departments were English Language Teaching Units (ELTUs). In this article, however, I refer to all of these as DELTs in order to prevent confusion.

2 The University of Sri Jayawardenapura's Faculty of Arts provides 10 hours per week for ESL, a rare instance where student time in the ESL class is prioritised. Ratnayaka (2017) provides a useful account of how this was achieved. 


\section{References}

Aturupane, H. (2011). Sri Lanka - Higher education for the twenty first century project: P113402 - Implementation status results report: Sequence 01 (English) (ISR2168). World Bank Group. http://documents.worldbank.org/curated/en/404101468759890390/Sri-Lanka-HigherEducation-for-the-Twenty-First-Century-Project-P113402-Implementation-Status-ResultsReport-Sequence-01

Aturupane, H. (2016). Sri Lanka - Higher education for the twenty first century project: P113402 - Implementation status results report: Sequence 12 (English) (ISR23889). World Bank Group. http://documents.worldbank.org/curated/en/127951466873723910/Sri-Lanka-Sri-LankaHigher-Education-for-the-Twenty-First-Century-Project-P113402-Implementation-StatusResults-Report-Sequence-12

Banya, K., \& Elu, J. (2001). The World Bank and financing higher education in Sub-Saharan Africa. Higher Education, 42(1), 1-34. http://www.jstor.org/stable/3448080

Brock-Utne, B. (2007). Worldbankification development of Norwegian assistance to education. Comparative Education, 43(3), 433-449. https://doi.org/10.1080/03050060701556455

Brock-Utne, B. (2010). Research and policy on the language of instruction issue in Africa. International Journal of Educational Development, 30(6), 636-645.

https://doi.org/10.1016/j.ijedudev.2010.03.004

Burford, J., \& Mulya, T. W. (2019). Neoliberalism in Thai and Indonesian Universities: Using photo-elicitation methods to picture space for possibility. In C. Manathunga \& D. Bottrell (Eds.), Resisting neoliberalism in higher education volume II: Prising open the cracks (pp. 219-246). Palgrave Macmillan.

Canagarajah, A. S. (1999). Resisting linguistic imperialism in English teaching. Oxford University Press.

Collins, C. S., \& Rhoads, R. A. (2010). The World Bank, support for universities, and asymmetrical power relations in international development. Higher Education, 59, 181-205. https://doi.org/10.1007/s10734-009-9242-9

Dundar, H., Millot, B., Riboud, M., Shojo, M., Aturupane, H., Goyal, S., \& Raju, D. (2017). Sri Lanka education sector assessment: Achievements, challenges, and policy options. World Bank Group. https://doi.org/10.1596/978-1-4648-1052-7

Gunesekera, M. (2005). The postcolonial identity of Sri Lankan English. Katha Publishers.

Heyneman, S. P. (2003). The history and problems in the making of education policy at the World Bank 1960-2000. International Journal of Educational Development, 23(3), 315-337. https://doi.org/10.1016/S0738-0593(02)00053-6

Heyneman, Stephen P. (2012). When models become monopolies: The making of education policy at the World Bank. Education Strategy in the Developing World: Revising the World Bank's Education Policy, 16, 43-62. https://doi.org/10.1108/S1479-3679(2012)0000016007 
Implementation completion and results report. (2010). Sri Lanka - Improving relevance and quality of undergraduate education project (English) (Report No. ICR00001659). World Bank Group. http://documents.worldbank.org/curated/en/491051468113652573/Sri-Lanka-ImprovingRelevance-and-Quality-of-Undergraduate-Education-Project

Implementation completion and results report (2016). Sri Lanka - Higher education for the twenty first century project (English) (Report No. ICR00003881). World Bank Group.

http://documents.worldbank.org/curated/en/752701484078286785/Sri-Lanka-HigherEducation-for-the-Twenty-First-Century-Project

Implementation completion report review. (2011). Sri Lanka - Improving relevance and quality of undergraduate education (English) (Report No. ICRR13570). World Bank Group.

http://documents.worldbank.org/curated/en/713101474630824288/Sri-Lanka-ImprovingRelevance-And-Quality-Of-Undergraduate-Education

Jones, P. W. (2006). World Bank financing of education: Lending, learning and development (2nd ed.). Routledge. https://doi.org/10.4324/9780203965931

Kabir, A. H. (2020). 'Network governance' and the formation of the strategic plan in the higher education sector in Bangladesh. Journal of Education Policy, 1-25.

https://doi.org/10.1080/02680939.2020.1717637

Kandiah, T. (2010). "Kaduwa": Power and the English language weapon in Sri Lanka. In S. Fernando, M. Gunesekera, \& A. Parakrama (Eds.), English in Sri Lanka: Ceylon English, Lankan English, Sri Lankan English (pp. 36-43). SLELTA.

Legal Dept of World Bank. (2003). Improving relevance and quality of undergraduate education project - Development credit agreement (English) (Conformed copy - C3781). World Bank Group.

http://documents.worldbank.org/curated/en/858411468340307163/Conformed-Copy-C3781Improving-Relevance-and-Quality-of-Undergraduate-Education-Project-Development-CreditAgreement

Mazrui, A. (2000). The World Bank, the language question, and the future of African education. In S. Federici, G. Caffentzis, \& O. Alidou (Eds.), A thousand flowers: Social struggles against structural adjustment in African universities (pp. 43-60). Africa World Press.

Minocha, S., Hristov, D., \& Reynolds, M. (2017). From graduate employability to employment: policy and practice in UK higher education. International Journal of Training and Development, 21(3), 235-248. https://doi.org/10.1111/ijtd.12105

Ortega, L. (2011). Second language acquisition. Routledge.

Parakrama, A. (1995). De-hegemonizing language standards: Learning from (post) colonial Englishes about English. Springer.

Perera, K., \& Canagarajah, S. (2010). Globalization and English teaching in Sri Lanka: Foreign resources and local responses. In V. Vaish (Ed.), Globalization of language and culture in Asia (pp. 106-119). Continuum. 
Phillipson, R. (2001). English for globalisation or for the world's people? International Review of Education, 47(3-4), 185-200. https://doi.org/10.1023/A:1017937322957

Project appraisal document IRQUE. (2003). Sri Lanka - Improving relevance and quality of undergraduate education (English) (Report No. 25386). World Bank Group. http://documents.worldbank.org/curated/en/815441468777043559/Sri-Lanka-ImprovingRelevance-and-Quality-of-Undergraduate-Education

Project appraisal document HETC. (2010). Sri Lanka - Higher education for the twenty first century project (English) (Report No. 49190-LK). World Bank Group.

http://documents.worldbank.org/curated/en/669901468103455055/Sri-Lanka-HigherEducation-for-the-Twenty-First-Century-Project

Punchi, L. (2001). Resistance towards the language of globalisation: The case of Sri Lanka. International Review of Education, 47(3/4), 361-378.

Ranasinghe, A., \& Logendra, R. (2015). Graduate employment, employable attributes and attribute gap in developing countries: A case study from Sri Lanka. July.

https://www.researchgate.net/publication/279704564

Ratnayaka, M. (2017). A thousand voiced choir. Godage.

Regmi, K. D. (2015). Lifelong learning: Foundational models, underlying assumptions and critiques. International Review of Education, 61(2), 133-151. https://doi.org/10.1007/s11159-015-9480-2

Regmi, K. D. (2016). World Bank in Nepal's education: Three decades of neoliberal reform. Globalisation, Societies and Education, 1-14. https://doi.org/10.1080/14767724.2016.1169517

Regmi, K. D. (2019). Higher education in Nepal: A handmaiden of neoliberal instrumentalism. Higher Education Policy, March, 1-19. https://doi.org/10.1057/s41307-019-00138-0

Rumnaz Imam, S. (2005). English as a global language and the question of nation-building education in Bangladesh. Comparative Education, 41(4), 471-486.

https://doi.org/10.1080/03050060500317588

Rutkowski, D. J. (2007). Converging us softly: How intergovernmental organizations promote neoliberal educational policy. Critical Studies in Education, 48(2), 229-247.

https://doi.org/10.1080/17508480701494259

Samaranayake, G. (2016). Expansion of university education, graduate unemployment and the knowledge hub in Sri Lanka. Social Affairs: A Journal for the Social Sciences, 1(4), 15-32. http://socialaffairsjournal.com/CurrentIssue/2.Expansion of University Education, Graduate Unemployment and the Knowledge Hub in Sri Lanka - Samaranayake.pdf

Senaratne, S., \& Gunarathne, N. (2010). Perceptions of students on improving relevance and quality of undergraduate education : An organizational development. International Research Conference on Management and Finance - 2010. 
Talmy, S. (2010). Qualitative interviews in applied linguistics: From research instrument to social practice. Annual Review of Applied Linguistics, 30, 128-148.

https://doi.org/10.1017/S0267190510000085

Torres, C. A., \& Schugurensky, D. (2002). The political economy of higher education in the era of neoliberal globalization: Latin America in comparative perspective. Higher Education, 43(4), 429-455. https://doi.org/10.1023/A:1015292413037

Verger, A., Edwards, D. B., \& Altinyelken, H. K. (2014). Learning from all? The World Bank, aid agencies and the construction of hegemony in education for development. Comparative Education, 50(4), 381-399. https://doi.org/10.1080/03050068.2014.918713

Wickramasinghe, V. (2018). Higher education in state universities in Sri Lanka: Review of higher education since colonial past through international funding for development. International Journal of Educational Management, 32(3), 463-478.

https://doi.org/10.1108/IJEM-01-2017-0028

Wikramanayake, D. H. (2015). Donor Aid to the Education Sector in Sri Lanka and the Achievement of Education Goals. In I.-H. Cheng \& S.-J. Chan (Eds.), International education aid in developing asia (pp. 199-220). Springer Science+Business Media.

https://doi.org/10.1007/978-981-287-456-6_11

World Bank Group. (2015). Sri Lanka: Ending poverty and promoting shared prosperity: A systematic country diagnostic (Report No. 99891). The World Bank. https://openknowledge.worldbank.org/handle/10986/23115 